\title{
Solar Tunnel Drying: Pretreatment on drying kinetic of plum tomatoes
}

\section{Sevil Karaaslan ${ }^{1 *}$ iD Kamil Ekinci $^{1}$ Barbaros Salih Kumbul $^{1}$}

${ }^{1}$ Isparta University of Applied Sciences (ISUBU), Faculty of Agricultural Sciences and Technologies, Department of Agricultural Machinery and Technologies Engineering, 32260, Isparta, Turkey. E-mail: sevilkaraaslan@isparta.edu.tr. "Corresponding author.

ABSTRACT: Drying of thin layer tomato was studied using a solar tunnel dryer under the ecological conditions of Isparta, Turkey. During drying process, solar irradiation, drying air temperature, relative humidity, and air velocity were measured constantly in different parts of the dryer. Drying runs were performed using plum tomatoes, characterized by an oval shape, intense red color. The change of tomatoes mass was measured daily. The color measurements of dried products were determined at the beginning and end of experiment. In this study, the fresh tomato samples were sorted, graded, washed in water and then sliced into quarters and halves before pretreated. Sun drying behavior of half and quarter sliced tomatoes pretreated with $10 \% \mathrm{NaCl}$ solution and non-pretreated was investigated. Results showed that the drying time for pretreated and non-pretreated samples was not significantly different. However, drying time and drying rates were affected by number of tomato slices (quarter and half). Drying characteristic curves were evaluated against thirteen mathematical models and the Midilli et al model was the best descriptive model for solar tunnel drying of thin layer tomato. Color analysis emphasized that if tomatoes are pretreated with $10 \%$ $\mathrm{NaCl}$ solution, they should be sliced in quarter for better quality.

Key words: Drying characteristics, tomato slices, tunnel dryer, mathematical modeling.

Secagem de Túnel Solar: $O$ efeito do pré-tratamento na secagem cinética de tomates de ameixa

RESUMO: A secagem do tomate de camada fina foi estudada usando um secador de túnel solar sob as condições ecológicas de Isparta, na Turquia. Durante o processo de secagem, a irradiação solar, a temperatura do ar de secagem, a umidade relativa e a velocidade do ar foram medidas constantemente em diferentes partes do secador. As operações de secagem foram realizadas com tomates ameixa, caracterizados por uma forma oval, cor vermelha intensa. A mudança de massa de tomates foi medida diariamente. As medidas de cor dos produtos secos foram determinadas no inicio e no final da experiência. Neste estudo, as amostras de tomate fresco foram classificadas, lavadas em água e depois cortadas em quartos e metades antes do pré-tratamento. O comportamento de secagem ao sol do tomate em fatias de meio e quarto prétratadas com solução de $\mathrm{NaCl}$ a $10 \%$ e sem pré-tratamento foi investigado. Os resultados mostraram que o tempo de secagem para amostras pré-tratadas e não pré-tratadas não foram significativamente diferentes. No entanto, o tempo de secagem e as taxas de secagem foram afetadas pelo número de fatias de tomate (trimestre e meio). As curvas características de secagem foram avaliadas contra treze modelos matemáticos, sendo que o modelo de Midilli et al foi o melhor modelo descritivo para secagem em túnel solar de tomate de camada fina. A análise de cores enfatizou que se os tomates forem pré-tratados com solução de $\mathrm{NaCl}$ a $10 \%$, eles devem ser cortados em fatias para melhor qualidade.

Palavras-chave: Características de secagem, fatias de tomate, secador de túnel, modelagem matemática

\section{INTRODUCTION}

Tomato (solanum lycopersicum) is the second most important vegetable after potato in the world (ABANO et al., 2011). Tomato production in the world was 1,6 billion tons in 2014 (FAOSTAT, 2015). The main tomato growing countries are China, India, United States of America, Turkey, Egypt, Iran, and Italy (FAOSTAT, 2015). Tomato is the most popular vegetable crop for culinary properties and its health benefits. Drying is one of the important techniques for preservation of agricultural products after harvest and the market share for dried products at high quality is increasing every day due to consumer' demands. Solar drying also utilizes solar energy which is widely available source of renewable energy (TIWARI, 2016). Conventional solar drying, which has been applied on the ground in open air, is the most commonly used method of drying in developing countries, because it is the simplest and the most inexpensive method of conserving foodstuffs (STILING et al., 2012). Even though conventional solar drying offers inexpensive way of drying operation, agricultural products are exposed to uncontrolled weather conditions and to the attack of insect, pests, microorganisms, and dust (BALA et al., 
2003) and harmful effects of UV radiation (STILING et al., 2012). Natural convection dryers can be locally manufactured at low-cost without needing power and energy from outer source. However, the natural convection solar dryers exhibit highly low buoyancy inside dryer (BALA et al., 2003). Furthermore, conventional dryers are not economic because of high energy cost (GURLEK et al., 2009). At the other side, solar tunnel drier can be operated by a fan driven by photovoltaic module and this system removes moisture inside dryer. Additionally, it was reported that fan power requirement from photovoltaic module is low. Solar tunnel drier was utilized for drying of many agricultural products such as fruits, vegetables, cereals, grain, legumes, oil seeds, spices and even fish and meat (BALA et al., 2003). Drying operation is performed to tomatoes for preservation purpose as well as alteration of taste, texture and flavor to satisfy consumer requirements and increase quality of the product for the market (BALA et al., 2003; GURLEK et al., 2009).

Fruits, vegetables and their dried forms are a good source of energy in terms of minerals and vitamins. However, during the process of dehydration, there are changes in nutritional quality. Product quality changes (color, texture) and nutritional quality must be maintained during the drying process. This makes the quality of the product increasingly important in dried vegetables and fruits. Improvement of such qualities can be achieved by pretreatments before drying. Appropriate pretreatments can improve the drying process by reducing drying time, providing better quality products and saving energy. (HII et al., 2012).

The main objective of this study was to use the solar tunnel dryer for thin layer drying of tomato. This study specifically focused on evaluation of the effects of salt pretreatment and slicing (quarter and half) tomatoes on the drying process using a solar tunnel dryer in Isparta conditions and to determine the best describing mathematical model to experimental data.

\section{MATERIALS AND METHODS}

\section{Materials}

A homogeneously sized tomato samples were used in this study as experimental material. Fresh tomatoes (Lycopersicum esculentum Mill. Cv. Rio Grande) were purchased from the supermarket in same brand name to provide the consistency of results for the experiment. Drying processes were performed using plum tomatoes, characterized by an oval shape intense red color. Tomatoes were selected manually from having average dimensions of $4 \pm 04$ $\mathrm{cm}$ diameter and $8 \pm 0.3 \mathrm{~cm}$ length.

\section{Drying Equipment}

A solar tunnel dryer constructed at Department of Agricultural Machinery and Technologies Engineering at Suleyman Demirel University was used in this study (Figure 1). It

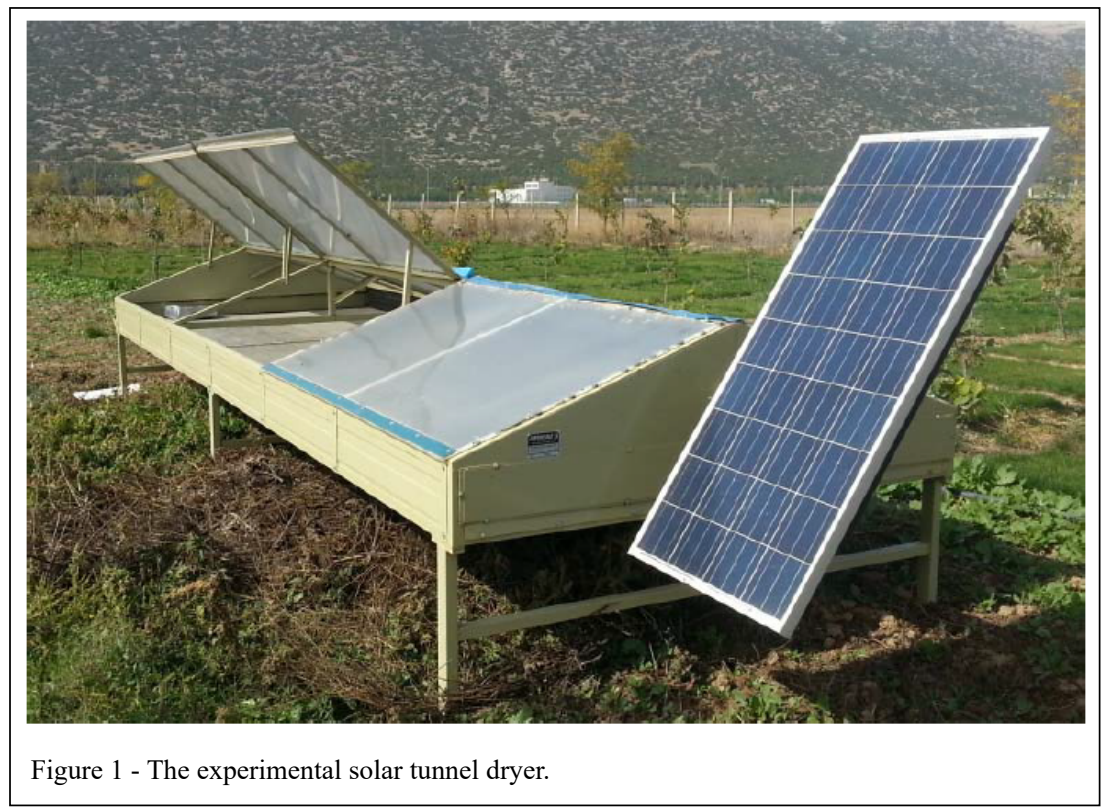

Ciência Rural, v.49, n.7, 2019. 
comprised of a flat plate solar collector, a drying tunnel, a solar cell module, and a small axial fan. All units are mounted on metal frame. The bottom of solar collector has hexagonal channels and is directly connected to drying tunnel. The bottom of solar tunnel dryer is painted black to absorb radiation. The collector is coated with a transparent polycarbonate material. The dryer is equipped with a $150 \mathrm{~W}$ solar cell module. A fan delivers air to the drying tunnel. Solar energy absorption area of the collector is $2 \mathrm{~m}$ length and $1.9 \mathrm{~m}$ width. The drying tunnel area is twice the area of collector. The dryer is oriented in east-west direction and its drying tunnel is not shaded by trees or buildings between 9:00 am and 5:00 pm.

\section{Drying Procedure}

The fresh tomato samples were sorted, graded, washed in water and then sliced into halves and quarters before pretreated. Tomato slices were immersed in $10 \% \mathrm{NaCl}$ solution for 3 min according to Latapi and Barrett (2006). Therefore, treatments were named as "non-pretreated-quarter, nonpretreated-half, pretreated-quarter and pretreatedhalf". Tomatoes weighted on a balance reading to $0.01 \mathrm{~g}$ (Sartorius GP3202, Germany). The pre-cut tomato samples (halves and quarters) to be dried were placed in a pre-weighed tray in one layer in the drying tunnel. About $1000 \mathrm{~g}$ samples of tomato slices were placed into trays and processed with salt for drying experiments. Drying experiment started after completion of the loading at 9:00 am and was paused at 5:00 pm. Weight loss of the tomato slices in the solar tunnel drier was measured during the drying period at one hour interval with a digital balance. In the afternoon after 5:00 pm, the samples of tomato in the solar tunnel drier were kept in the drier in the environmental conditions. Then, samples were exposed to the same weather conditions. The drying process was terminated until no mass change was detected. Experiments were carried out on July 19-23, 2017. Solar irradiance were measured hourly (09:00 am- 17:00 pm) on a horizontal surface by pyranometer. Relative humidity and temperature of drying air were measured using $\mathrm{K}$ type thermocouples and DT-3 hygrometer at the drying tunnel of dryer. Air velocity at the outlet of drying tunnel was measured by a hotwire anemometer.

Tomato samples were subjected to the moisture analysis at the oven at the temperature of $105{ }^{\circ} \mathrm{C}$ for 24 hours. The moisture ratio (MR) was calculated based on moisture content as a function of time $(\mathrm{t})(\mathrm{M}(\mathrm{t}))$, initial moisture content of samples $\left(\mathrm{M}_{0}\right)$, and equilibrium moisture content of samples $\left(\mathrm{M}_{\mathrm{e}}\right)$.
$\mathrm{MR}=\frac{\mathrm{M}(\mathrm{t})-\mathrm{M}_{\mathrm{e}}}{\mathrm{M}_{0}-\mathrm{M}_{\mathrm{e}}}$

All moisture contents were reported as wet basis (\%, w.b). Simplification of MR in Eq. 1 as M/Mo was suggested by Diamente and Munro, 1993; Elicin and Sacılık, 2005 due to the continuous fluctuation of relative humidity of drying air under solar tunnel dryer conditions. Therefore, the drying rate as $\mathrm{g}_{\text {water }} / \mathrm{h}$ (DR) of the tomatoes samples was determined by Eqs. 2:

$\mathrm{DR}=\frac{\mathrm{M}_{\mathrm{t}+\mathrm{dt}}-\mathrm{M}_{\mathrm{t}}}{\mathrm{dt}}$

Where $\mathrm{M}_{\mathrm{t}+\mathrm{dt}}$ is the moisture content at $t+\mathrm{d} t$ (g water/g dry matter). A non-linear regression analysis (Sigma Plot 12.00) was applied to experimentally obtained MR as a function of time using drying models given in table 1 . The constants (a, n, b, c, m, k, and g) of models tested in table 1 were determined based on the non-linear regression analysis. Performance of models was evaluated by coefficient of determination $\left(\mathrm{R}^{2}\right)$, the standard error of estimate (SEE), and residual sum of square (RSS).

Color measurements of both fresh and dried tomato samples using solar tunnel drier were performed using a color meter (Minolta Chroma Meter CR 400, Osaka, Japan). Color of samples was determined at initially and predefined time intervals. Values were reported as average \pm standard deviation in the study. The color values consisted of three different parameters: (1) whiteness or brightness/ darkness $\left(\mathrm{L}^{*}\right)$, (2) redness/greenness (a*), and (3) yellowness/blueness ( $\left.b^{*}\right)$. Additionally, Chroma (C) and Hue angles $(\alpha)$ were determined based on values of $\mathrm{L}^{*}, \mathrm{a}^{*}$, and $\mathrm{b}^{*}$ for dried tomatoes.

$\mathrm{C}=\sqrt{\left(a^{* 2}+b^{* 2}\right)}$

$a=\tan -1\left(b^{*} / a^{*}\right)$

\section{Statistical analysis}

Statistical analysis was conducted using the Sigma Plot (Scientific Graph System, version 9.00). Non-linear regression analysis was performed using Sigma-Plot (SPSS Inc., version 9.00) to estimate the parameters of equations. Regression results included microwave drying of spinach leaves under various microwave output power, combination and hot air; SEE, standard error of estimate; $R^{2}$, coefficient of determination; and RSS, residual sum of square.

Factorial design was selected for the color analysis. Two apple slices (quarter and half) and two treatment levels (non-pretreated and pretreated) were chosen. Number of replications in all sub-groups is 15. The data from color analysis was subjected to variance analysis. Additionally, Dunnet test was 
Table 1 - Mathematical models tested for the moisture ratio values oftomato samples.

\begin{tabular}{|c|c|c|c|}
\hline No & Model name & Model Equation & References \\
\hline 1 & Alibas & $M R=a \exp \left(\left(-k t^{n}\right)+b t\right)+g$ & Alibas 2012 \\
\hline 2 & Diffusion approach & $M R=a \exp (-k t)+(1-a) \exp (-k b t)$ & Artnaseaw et al. 2010 \\
\hline 3 & Henderson and pabis & $M R=a \exp (-k t)$ & Doymaz, 2014 \\
\hline 4 & Logarithmic & $M R=a \exp (-k t)+c$ & Akpinar 2008 \\
\hline 5 & Logistic & $M R=a_{0} /(1+a \exp (k t))$ & Soysal 2005 \\
\hline 6 & Midilli et al. & $M R=a \exp \left(-k t^{m}\right)+b t$ & Midilli et al. 2002 \\
\hline 7 & Newton & $\mathrm{MR}=\exp (-\mathrm{kt})$ & Toğrul \& Pehlivan 2002 \\
\hline 8 & Page & $\mathrm{MR}=\exp \left(-\mathrm{kt}^{\mathrm{n}}\right)$ & Akpinar 2008 \\
\hline 9 & Two term & $M R=a \exp \left(-k_{0} t\right)+b \exp \left(-k_{1} t\right)$ & Yaldiz et al.2001 \\
\hline 10 & Two term exponential & $M R=a \exp (-k t)+(1-a)^{*} \exp \left(-m^{*} k^{*} x\right)$ & Sharaf-Elden et al. 1980 \\
\hline 11 & Verma et al. & $M R=a \exp (-k t)+(1-a) \exp (-g t)$ & Verma et al. 1985 \\
\hline 12 & Wang and Singh & $\mathrm{MR}=1+\mathrm{at}+b \mathrm{t}^{2}$ & Babalis et al. 2006 \\
\hline 13 & Weibull distribution & $M R=a-b \exp \left[-\left(k t^{n}\right)\right]$ & Babalis et al. 2006 \\
\hline
\end{tabular}

used to determine the difference in the means of all subgroups and control (fresh tomatoes).

\section{RESULTS AND DISCUSSION}

Solar drying of sliced tomatoes was conducted on July in 2017. Throughout the experiment, the weather was sunny and no rain was recorded. The experiment was conducted only once and lasted for 5 days. The pattern of temperature and relative humidity of the drying air is shown in figure 2. Air temperature changed from 23.0 to $58.1{ }^{\circ} \mathrm{C}$ and relative humidity ranged from $24-65 \%$ during the experiment. The change of air velocity as a function of time and days is given in figure 3 . As can be seen from figure 3, the velocities obtained from fans peaked at approximately middle of days. The air velocities synchronized with air temperatures thereby modulating the drying temperature. More energy received by the collector at the high solar irradiance (Figure 4) led to increase drying air temperature which was equated by the increased air velocity (BALA et al., 2003). As the fan was powered by the solar cell, the air flow velocity changed as a function of solar irradiation (Figure 4). Solar irradiance values measured between July 19 and July 23, 2017 are showed figure 4. Solar irradiance values ranged from 990 to $1070 \mathrm{~W} \mathrm{~m}^{-2}$ levels at noon (12:00 pm-14:00 pm). Solar irradiances were at low

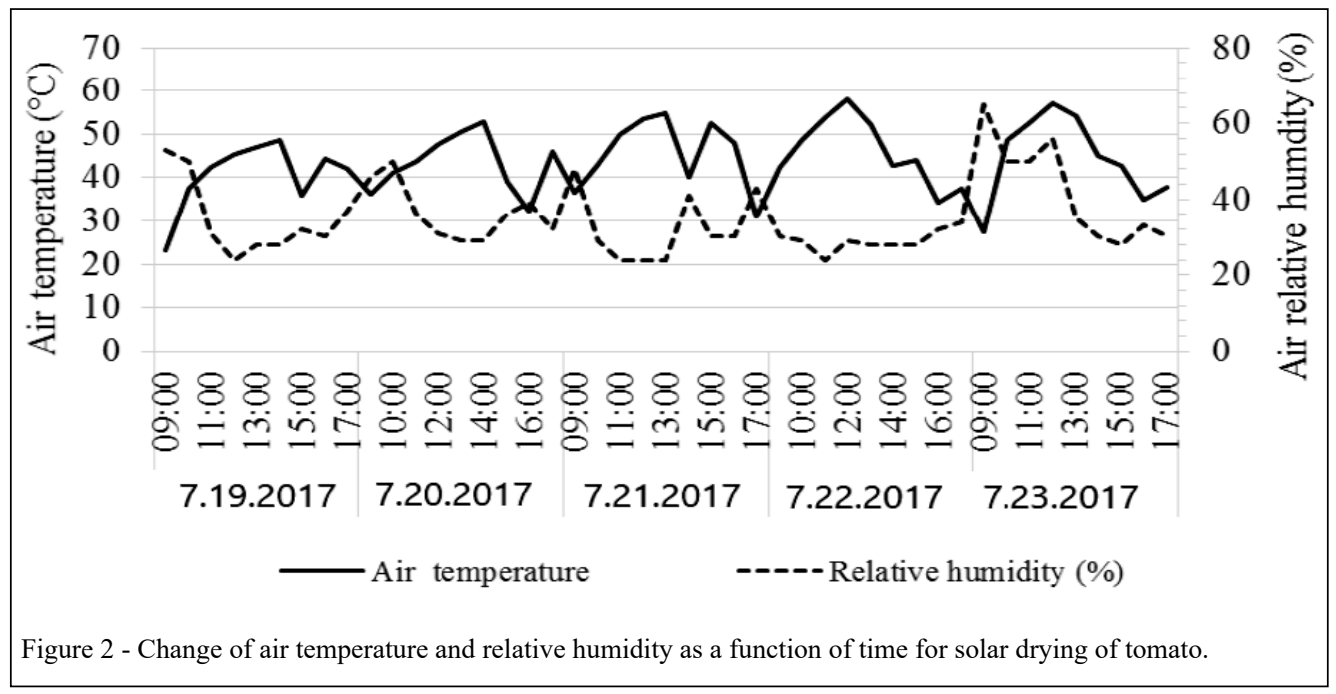

Ciência Rural, v.49, n.7, 2019. 


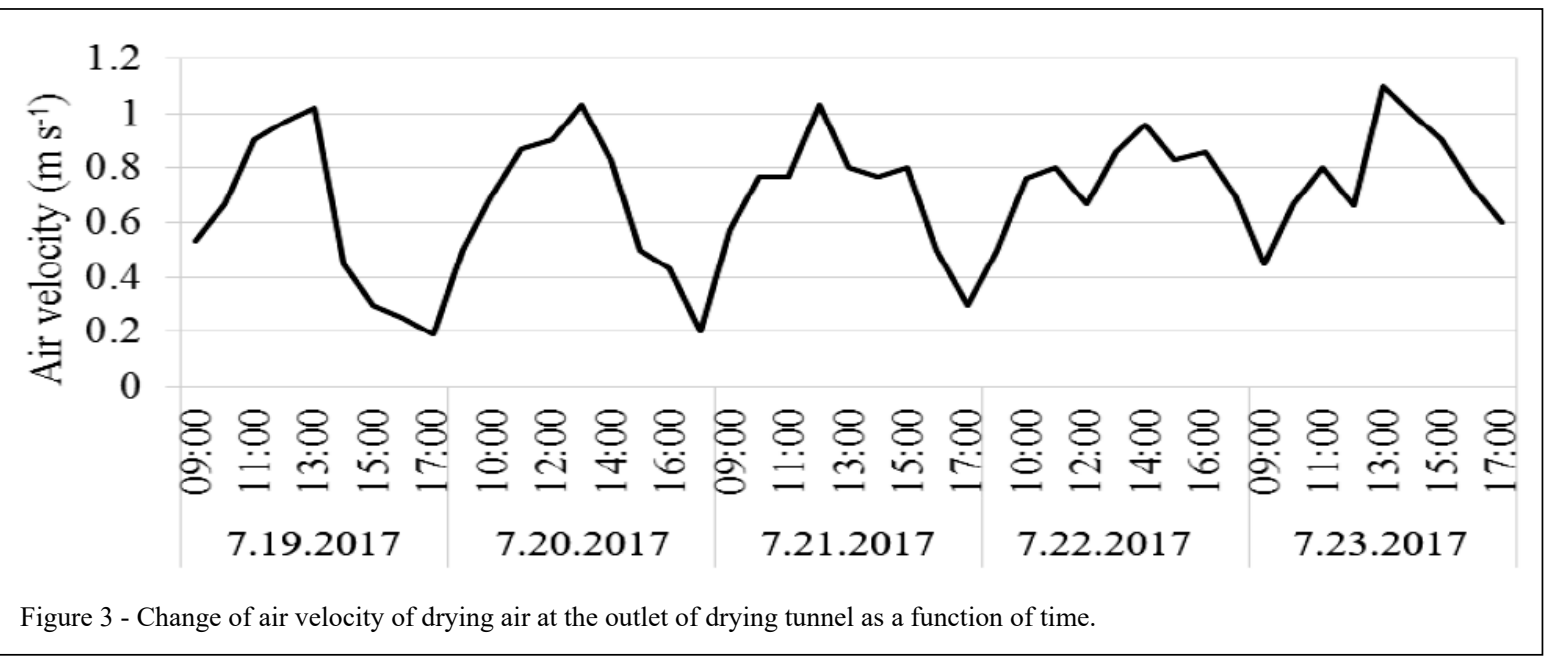

level in the morning and afternoon due to the variation of the solar angles. Solar irradiance values changed over the normal levels for the geographical coordinates of Isparta City. In general, it was difficult to measure directly the airflow rate of the solar tunnel dryer because the air velocity varied with time and position on the perpendicular to the flow. The fan, which was not controlled, was operated continuously as long as the solar cell module supplied power.

The influence of pretreatment of thin layer sliced tomatoes on moisture ratio, drying rate, and color values were also investigated. The drying time necessary for reduction of initial moisture content from $(90.9 \%$ w.b.) to the desired final moisture content up to (17.2\% w.b.) for non-pretreated samples at halves and quarters was 2880 and $1440 \mathrm{~min}$ while drying time for pretreated samples at halves and quarters was e 2640 and $1440 \mathrm{~min}$, respectively. These results showed that slicing quarter of tomato reduced the drying time up to $50 \%$ and $45 \%$, respectively for both non-pretreated and pretreated tomatoes. Salt solution was not effective on reduction of drying time for tomato samples pretreated with salt. As shown in figure 5, moisture ratio decreased continuously with decreasing moisture content. Moisture ratios for both non-pretreated-quarter and pretreated-quarter samples were higher as compared to both nonpretreated-half and pre-treated half samples for all

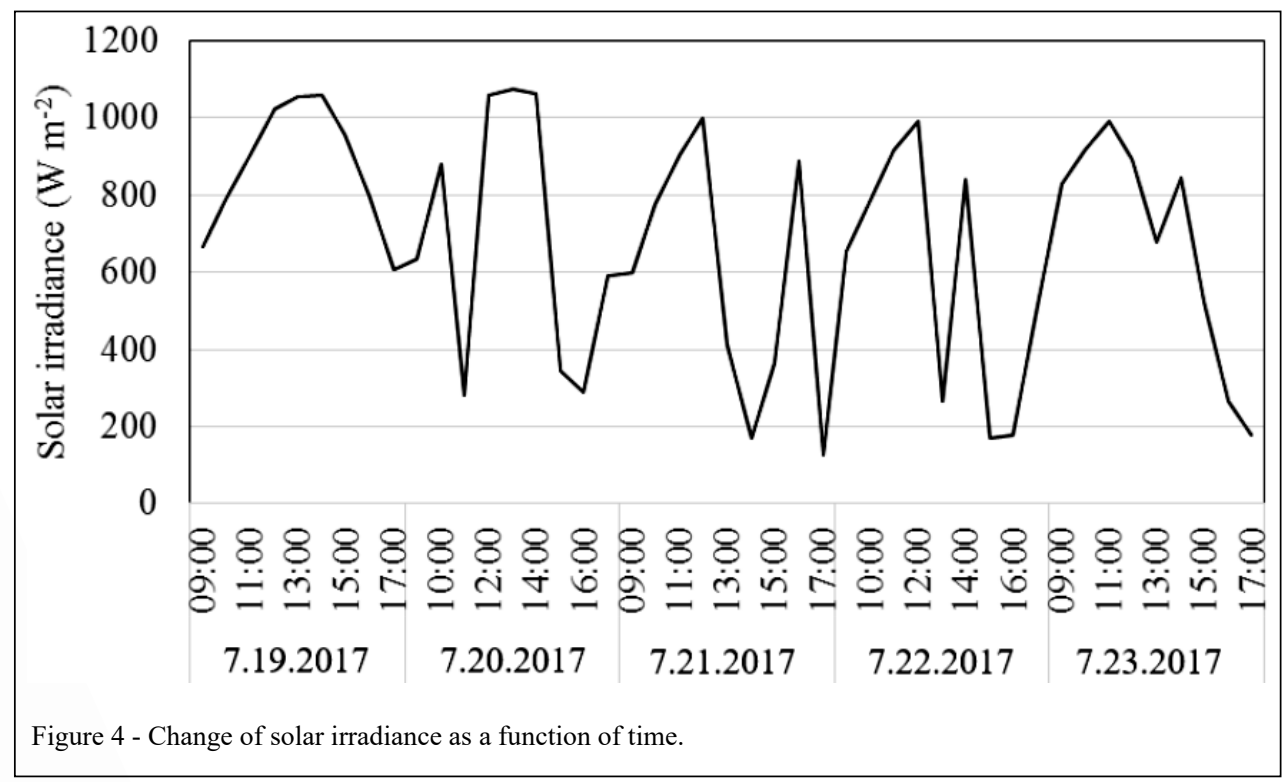

Ciência Rural, v.49, n.7, 2019. 


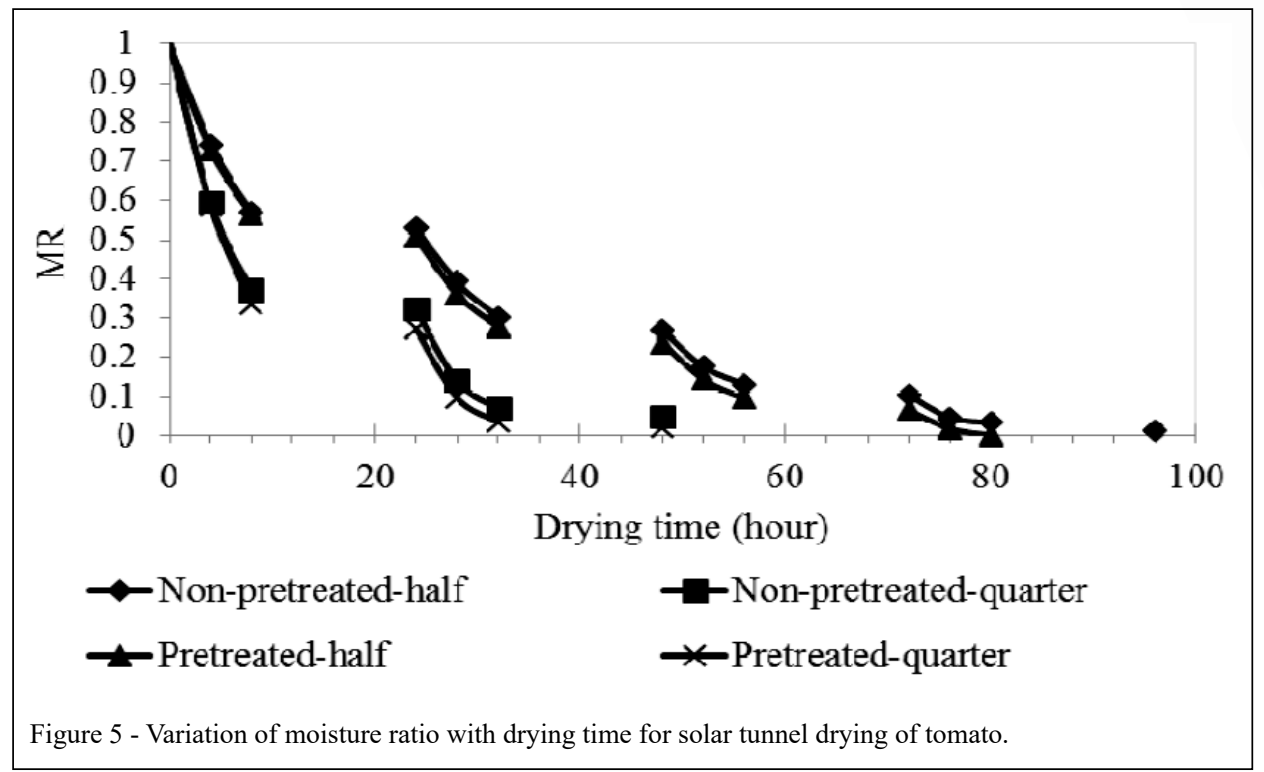

drying temperatures. Absence of lines in drying cycle in each day in figure 5 indicates the night periods (Saçılık and Eliçin, 2005).

The change of drying rate as a function of time is depicted in figure 6 in solar tunnel drier. Results showed that the drying rate was $78-80 \mathrm{~g} / \mathrm{h}$ within four hours and at the final stage of drying rate decreased to $1.5-2.5 \mathrm{~g} / \mathrm{h}$ for both non-pretreated quarter and pretreated quarter samples. At the other side, it was observed that for both non-pretreated half and pretreated half samples, the drying rate was 52$53 \mathrm{~g} / \mathrm{h}$ within four hours and declined to $1.25-2.91 \mathrm{~g} / \mathrm{h}$ at the final stage of drying. The drying rate sharply increased within four hours and then decreased. This behavior was periodic and gradually diminishing in magnitude on each day of drying. It can be said that the drying rate of quarter samples was higher than that of half samples in solar tunnel drier.

Table 2 shows the outcomes of nonlinear regression analysis applied to the thirteen drying

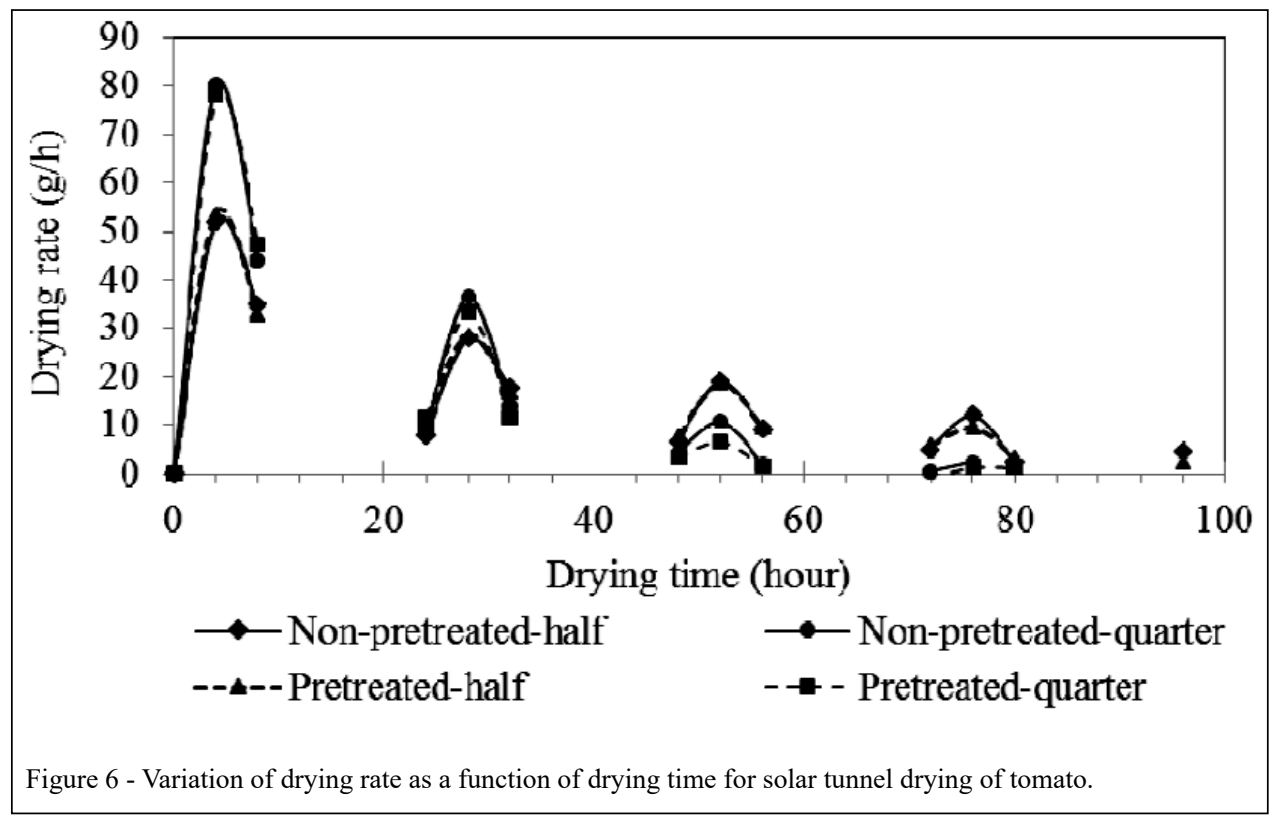

Ciência Rural, v.49, n.7, 2019. 
Table 2 - Results of nonlinear regression analysis of fitting the thirteen drying models to the experimental data for solar tunnel drying of tomato samples.

\begin{tabular}{|c|c|c|c|c|c|c|c|c|c|c|c|c|}
\hline \multirow[b]{2}{*}{ Model No } & \multicolumn{3}{|c|}{-----Non-pretreated-half----- } & \multicolumn{3}{|c|}{---Non-pretreated-quarter--- } & \multicolumn{3}{|c|}{--------Pretreated-half-------- } & \multicolumn{3}{|c|}{------Pretreated-quarter----- } \\
\hline & $\mathrm{R}^{2}$ & SEE & RSS & $\mathrm{R}^{2}$ & SEE & RSS & $\mathrm{R}^{2}$ & SEE & RSS & $\mathrm{R}^{2}$ & SEE & RSS \\
\hline 1 & 0.9846 & 0.0461 & 0.0170 & 0.9918 & 0.0535 & 0.0057 & 0.9748 & 0.0621 & 0.0270 & 0.9937 & 0.0488 & 0.0048 \\
\hline 2 & 0.9885 & 0.0357 & 0.0127 & 0.9874 & 0.0468 & 0.0087 & 0.9872 & 0.0391 & 0.0137 & 0.9905 & 0.0424 & 0.0072 \\
\hline 3 & 0.9888 & 0.0337 & 0.0125 & 0.9876 & 0.0415 & 0.0086 & 0.9872 & 0.0370 & 0.0137 & 0.9905 & 0.0379 & 0.0072 \\
\hline 4 & 0.9928 & 0.0283 & 0.0080 & 0.9879 & 0.0459 & 0.0084 & 0.9937 & 0.0273 & 0.0067 & 0.9923 & 0.0381 & 0.0058 \\
\hline 5 & 0.9896 & 0.0340 & 0.0116 & 0.9878 & 0.0460 & 0.0085 & 0.9890 & 0.0363 & 0.0118 & 0.9907 & 0.0419 & 0.0070 \\
\hline 6 & 0.9958 & 0.0227 & 0.0046 & 0.9917 & 0.0441 & 0.0058 & 0.9967 & 0.0210 & 0.0035 & 0.9937 & 0.0401 & 0.0048 \\
\hline 7 & 0.9885 & 0.0325 & 0.0127 & 0.9874 & 0.0382 & 0.0087 & 0.9872 & 0.0353 & 0.0137 & 0.9905 & 0.0346 & 0.0072 \\
\hline 8 & 0.9885 & 0.0340 & 0.0127 & 0.9880 & 0.0409 & 0.0084 & 0.9876 & 0.0365 & 0.0133 & 0.9906 & 0.0377 & 0.0071 \\
\hline 9 & 0.9888 & 0.0372 & 0.0125 & 0.9876 & 0.0536 & 0.0086 & 0.9872 & 0.0414 & 0.0137 & 0.9905 & 0.0490 & 0.0072 \\
\hline 10 & 0.9885 & 0.0357 & 0.0127 & 0.9887 & 0.0443 & 0.0078 & 0.9872 & 0.0391 & 0.0137 & 0.9905 & 0.0424 & 0.0072 \\
\hline 11 & 0.9868 & 0.0382 & 0.0146 & 0.9874 & 0.0468 & 0.0087 & 0.9872 & 0.0391 & 0.0137 & 0.9905 & 0.0424 & 0.0072 \\
\hline 12 & 0.9763 & 0.0489 & 0.0263 & 0.9727 & 0.0615 & 0.0189 & 0.9795 & 0.0468 & 0.0219 & 0.9789 & 0.0565 & 0.0159 \\
\hline 13 & 0.9954 & 0.0239 & 0.0051 & 0.9916 & 0.0441 & 0.0058 & 0.9963 & 0.0221 & 0.0039 & 0.9936 & 0.0401 & 0.0048 \\
\hline
\end{tabular}

models to the experimental data for non-pretreatedhalf, non-pretreated-quarter, pretreated-half and pretreated-quarter samples with $\mathrm{R}^{2}$, SEE, and RSS. The best model describing drying of tomatoes in given conditions was determined based on $\mathrm{R}^{2}$ with the lower value of SEE and RSS, which are evaluation criteria used to compare the statistical validity of the fit. Results showed that the $\mathrm{R}^{2}$, SEE, and RSS values of nonlinear regression analysis ranged from 0.9727 to 0.9967 , from 0.0210 to 0.0621 , and from 0.0035 to 0.0270 , respectively (Table 2). Furthermore, Midilli et al model yielded the highest $\mathrm{R}^{2}(0.9958,0.9916$, 0.9967 , and 0.9936) for non-pretreated-half, nonpretreated-quarter, pretreated-half and pretreatedquarter samples, respectively, with the lowest SEE and RSS values (Table 2). At given conditions, this model was chosen as the best describing model based on evaluation criteria and model constants such as a, $\mathrm{k}, \mathrm{b}$, and $\mathrm{m}$, which were regressed as a function of time were presented in table 3 .
The color is the most significant properties of dried crops (Saçılık and Eliçin, 2005). Color values measured for fresh and dried tomato slices in the solar tunnel drier are given in table 4. $\mathrm{L}^{*}, \mathrm{a}^{*}, \mathrm{~b}^{*}, \mathrm{C}$, and $\alpha$ values of fresh tomato were $32.03 \pm 1.00,29.26 \pm 2.03,13.58 \pm 0.21,32.33 \pm 1.74$, and $25.33 \pm 2.04$, respectively. Results of Dunnet test showed that the mean values of fresh tomato were higher than those of sub-groups. Variance analysis on results of $L^{*}, b^{*}$, and $\alpha$ showed that interaction (slices $\mathrm{x}$ treatments) and differences on the sub-group means were not statistically significant. The results of Dunnet test showed that all color values of the fresh tomato sample were significantly different from the values of dried tomato samples $(\mathrm{P}<0.05)$ except for sub-groups of non-pretreated-quarter. ASHEBIR et al. (2009) determined that $\mathrm{L}^{*}$ values of the dried tomato slices was significantly decreased at hot-air dried tomato samples compared to the fresh tomatoes.

Table 3 - Non-linear regression analysis results of semi-empirical Midilli et al. equation for solar tunnel drying of tomato.

\begin{tabular}{lccccc}
\hline Treatments & Constants & $\mathrm{R}^{2}$ & $\mathrm{SEE}( \pm)$ & $\mathrm{RSS}( \pm)$ \\
\hline Non-pretreated-half & $\mathrm{k}=0.9971 \mathrm{a}=0.0903 \mathrm{~m}=0.7957 \quad \mathrm{~b}=-0.0030$ & 0.9958 & 0.0227 & 0.0046 \\
Non-pretreated-quarter & $\mathrm{k}=0.9998 \mathrm{a}=0.1751 \quad \mathrm{~m}=0.7436 \quad \mathrm{~b}=-0.0052$ & 0.9916 & 0.0441 & 0.0058 \\
Pretreated-half & $\mathrm{k}=0.9974 \mathrm{a}=0.0941 \mathrm{~m}=0.7921 \mathrm{~b}=-0.0038$ & 0.9967 & 0.210 & 0.0035 \\
Pretreated-quarter & $\mathrm{k}=1.0000 \mathrm{a}=0.1568 \mathrm{~m}=0.8603 \quad \mathrm{~b}=-0.0036$ & 0.9936 & 0.0401 & 0.0048 \\
\hline
\end{tabular}

Ciência Rural, v.49, n.7, 2019. 
Table 4 - Effect of solar tunnel drying on the color parameters of tomato samples.

\begin{tabular}{|c|c|c|c|c|c|}
\hline Color parameters & Slices & Fresh tomato & Non-pretreated & Pretreated & Means \\
\hline \multirow{3}{*}{$\mathrm{L}^{*}$} & Quarter & \multirow{2}{*}{$32.00 \pm 1.00$} & $26.29 \pm 0.55^{\#}$ & $26.47 \pm 0.45^{\#}$ & $26.38 \pm 0.35$ \\
\hline & Half & & $26.91 \pm 0.54^{\#}$ & $25.54 \pm 0.80^{\#}$ & $26.22 \pm 0.49$ \\
\hline & Means & & $26.60 \pm 0.38$ & $26.00 \pm 0.46$ & \\
\hline \multirow{2}{*}{$a^{*}$} & Quarter & \multirow{2}{*}{$29.26 \pm 2.03$} & $16.35 \pm 0.84^{\#} \mathrm{Ba}^{1}$ & $19.89 \pm 0.53^{\#} \mathrm{Aa}$ & $18.12 \pm 0.59$ \\
\hline & Half & & $18.51 \pm 1.26^{\#} \mathrm{Aa}$ & $17.91 \pm 0.99^{\#} \mathrm{Aa}$ & $18.21 \pm 0.79$ \\
\hline \multirow{4}{*}{$b^{*}$} & Means & & $17.43 \pm 0.77$ & $18.90 \pm 0.58$ & \\
\hline & Quarter & \multirow{2}{*}{$13.58 \pm 0.21$} & $6.87 \pm 0.28^{\#}$ & $7.99 \pm 0.22^{\#}$ & $7.43 \pm 0.20$ \\
\hline & Half & & $7.42 \pm 0.46^{\#}$ & $7.26 \pm 0.35^{\#}$ & $7.34 \pm 0.29$ \\
\hline & Means & & $7.15 \pm 0.27$ & $7.62 \pm 0.22$ & \\
\hline \multirow{3}{*}{$\mathrm{C}$} & Quarter & \multirow{2}{*}{$32.33 \pm 1.74$} & $17.74 \pm 0.87^{\#} \mathrm{Ba}$ & $21.45 \pm 0.53^{\#} \mathrm{Aa}$ & $19.59 \pm 0.61$ \\
\hline & Half & & $19.95 \pm 1.34^{\#} \mathrm{Aa}$ & $19.33 \pm 1.04^{\#} \mathrm{Aa}$ & $19.64 \pm 0.84$ \\
\hline & Means & & $18.85 \pm 0.81$ & $20.39 \pm 0.61$ & \\
\hline \multirow{3}{*}{$\alpha$} & Quarter & \multirow{2}{*}{$25.33 \pm 2.04$} & $22.95 \pm 0.46$ & $21.96 \pm 0.60^{\#}$ & $22.46 \pm 0.38$ \\
\hline & Half & & $22.08 \pm 0.48^{\#}$ & $22.18 \pm 0.36^{\#}$ & $22.13 \pm 0.29$ \\
\hline & Means & & $22.52 \pm 0.34$ & $22.07 \pm 0.34$ & \\
\hline
\end{tabular}

\#:shows the significant difference between fresh tomato and subgroups.

1: Capital letter indicates the differences of treatments in each slice while lower case letter indicates the differences in each treatment.

As for $\mathrm{a}^{*}$ and $\mathrm{C}$, variance analysis yielded that interaction (slices $\mathrm{x}$ treatments) was statistically significant $(\mathrm{P}<0.05)$. It means that differences in terms of treatments exist based on tomato slices and vice versa. a*values of dried product did not change much among all subgroups of slices. This is valid for two treatments. ASHEBIR et al. (2009) reported higher values in magnitude of the red and yellow colors and brightness of the red color for hot-air dried tomato compared to fresh tomatoes samples. At the other side, chroma (C) represents the extent of color saturation and is in proportion to the strength of the color (MASKAN, 2001). Results showed that $\mathrm{C}$ values of the fresh tomato samples were statistically different from the values of dried products $(\mathrm{P}<0.05)$. Comparing to fresh tomato samples, $\mathrm{C}$ values of the all dried products significantly decreased. The findings from this study were in agreement with those reported by BARREIRO et al. (1997) on drying of tomatoes. Furthermore, MASKAN (2001) reported that little change in $\mathrm{C}$ values between fresh and dried fruit and they were not different in all drying methods. Nevertheless, $\alpha$ values of the dried tomato samples tended to decrease in all subgroups of slicestreatments except for non-pretreated-quarter subgroups in comparison with fresh tomato. Similar observations were also obtained by MASKAN
(2001) for all drying methods and reported that $\alpha$ values decreased during drying processes.

In conclusion, if tomatoes are sliced in quarter, pretreated tomatoes have higher values compared to non-pretreated tomatoes in terms of color parameters. Furthermore, it can be highlighted that if tomatoes are pretreated with $10 \% \mathrm{NaCl}$ solution they should be sliced in quarter for better quality and if tomatoes are sliced in half, treatment in this study is not so important.

\section{CONCLUSIONS}

Slicing tomatoes samples in quarter decreased drying time up to about $8.3 \%$ as compared to slicing tomatoes samples in half. Effect of treating tomato samples with salt solution was not significant on reduction of drying time. Higher drying rate was calculated for quarter samples than half samples in solar tunnel drier. Among the all model tested, MIDILLI et al. Model was the best descriptive model for solar tunnel drying of thin layer tomato. Color analysis emphasized that if tomatoes are pretreated with $10 \% \mathrm{NaCl}$ solution, they should be sliced in quarter for better quality. Furthermore, treating tomato sample sliced in half does not have any significant impact on color quality of tomato samples. 


\section{DECLARATION OF CONFLICT OF INTERESTS}

The authors declare no conflict of interest. The founding sponsors had no role in the design of the study; in the collection, analyses, or interpretation of data; in the writing of the manuscript, and in the decision to publish the results.

\section{AUTHORS' CONTRIBUTIONS}

All authors contributed equally for the conception and writing of the manuscript. All authors critically revised the manuscript and approved of the final version..

\section{REFERENCES}

ABANO, EE., et al (2011). Influence of air temperature on the drying kinetics and quality of tomato slices. Journal of Food Processing and Technology. 2:123 Available from: $<$ http://dx.doi. org/10.4172/2157-7110.1000123>. Accessed: Nov. 20, 2011. doi: $10.4172 / 2157-7110.1000123$

AKPINAR, A.K., (2008). Mathematical modeling and experimental investigation on sun and solar drying of white mulberry. J. of Mechanical Science and Techn. 22 pp:1544-1553. Available from: $<$ https://www.semanticscholar.org/paper/Mathematical-modellingand-experimental-on-sun-and-Akpinar/1802e34503bc79bf08e $5 \mathrm{f}$ d93ba6996970ebf7cb1>. Accessed: Sep. 11, 2008. doi: 10.1007/ s12206-008-0508-4.

ALIBAS, I., (2012). Selection of the best suitable thin-layer drying mathematical model for vacuum dried red chili pepper. J. Biol. Environ. Scı. 6(17) pp:161-170. Available from: <https://www. researchgate.net/profile/Ilknur_Alibas/publication/260019874_ Selection of a the Best Suitable Thin-Layer Drying Mathematical_Model_for_Vacuum_Dried_Red_Chili_Pepper/ links/56ba40b908ae0a6bc955523b.pdf>. Accessed: Jul. 15, 2012.

ARTNASEAW, A., et al (2010). Development of a vacuum heat pump dryer for drying chili. Biosyst. Eng. 105. pp:130-138. Available from: <https://www.sciencedirect.com/science/article/ pii/S1537511009003109>. Accessed: Jan. 27, 2010. doi: 10.1016/j. biosystemseng.2009.10.003.

ASHEBIR, D., et al (2009). Change in color and other fruit quality characteristics of tomato cultivars after hot-air drying at low final-moisture content. International Journal of Food Sciences and Nutrition. 60(S7): 308-315. Available from: <https:// www.tandfonline.com/doi/full/10.1080/09637480903114128>. Accessed: Sep. 21, 2009. doi: 10.1080/09637480903114128.

BABALIS, S.J., et al (2006). Evaluation of thin layer drying models for describing drying kinetics of figs (Ficus carica). Journal of Food Engineering. 75(2):205-214. Available from: <https:// www.sciencedirect.com/science/article/pii/S0260877405002414>. Accessed: Sep. 25, 2009. doi: 10.1016/j.jfoodeng.2005.04.008.

BALA, B.K., et al (2003). Solar Drying of Pineapple Using Solar Tunnel Drier. Renewable Energy. 28. pp:183-190. Available from: $<$ https:// www.sciencedirect.com/science/article/pii/S0960148102000344>. Accessed: Feb. 23, 2003. doi: 10.1016/S0960-1481(02)00034-4.

BARREIRO, J.A., et al (1997). Kinetics of color change of double concentrated tomato paste during thermal treatment. J. Food Eng.,
33: 359-371. Available from: <https://www.sciencedirect.com/ science/article/pii/S0260877497000356>. Accessed: Aug. 13, 1997. doi: 10.1016/S0260-8774(97)00035-6.

DIAMENTE, L.M., MUNRO, P.A., (1993). Mathematical modeling of the thin layer solar drying of sweet potato slices. Solar Energy. 51. pp: 271-276. Available from: $<$ https://www. sciencedirect.com/science/article/pii/0038092X93901225>. Accessed: Oct. 09, 1993. doi: 10.1016/0038-092X(93)90122-5.

DOYMAZ, I., (2014). Suitability of thin-layer drying models for infrared drying of peach slices. Journal of food processing and preservation. 38 (6). pp: 2232-2239. Available from: <https:// onlinelibrary.wiley.com/doi/10.1111/jfpp.12277>. Accessed: May, 19 ,2014. doi: $10.1111 /$ jfpp. 12277 .

ELICIN, A.K., and SACILIK, K., (2005). An Experimental Study for Solar Tunnel Drying of Apple. Journal of Agricultural Sciences. 11 (2). pp:207-211. Available from: <https://www.researchgate.net/publication/237409337 An Experimental Study for Solar_Tunnel_Drying_of_Apple>. Accessed: Jan. 13, 2005. doi: 10.1501/Tarimbil 0000000421 .

FAOSTAT. Food and Agriculture Organization (FAO), Statistical Data. 2015, FAO. Available from: <http://faostat.fao.org/site/339/ default $>$. Accessed: Jan. 13, 2005

GURLEK, G., et al (2009). Solar Tunnel Drying Characteristics and Mathematical Modelling of Tomato. Journal of Thermal Science and Technology. 29,1, pp:15-23. Available from: $<$ http://citeseerx.ist.psu. edu/viewdoc/download?doi=10.1.1.552.2816\&rep=rep1\&type $=$ pdf $>$. Accessed: Jan. 17, 2005.

LATAPI, G., Barrett, D.M., (2006). Influence of Pre-drying treatments on Quality and Safety of Sun-dried Tomatoes. Part II. Effects of Storage on Nutritional and Sensory Quality of Sun-dried Tomatoes Pretreated with Sulfur, Sodium Metbisulfite, or Salt. Journal of Food Science. Vol:1 Nr:1 pp:S32-S37. Available from: $<$ https://onlinelibrary.wiley.com/doi/10.1111/j.1365-2621.2006. tb12402.x>. Accessed: May, 31, 2006. doi: 10.1111/j.13652621.2006.tb12402.x.

MASKAN, M., (2001). Kinetics of colour change of kiwifruits during hot air and microwave drying. Journal of Food Engineering. 48(2): 169-175. Available from: $<$ https://www.sciencedirect.com/science/article/pii/ S0260877400001552>. Accessed: May, 16, 2001. doi: 10.1016/S0260-8774(00)00155-2.

MIDÍLLİ, A., et al (2002). A new model for single layer drying. Dry Technol. 120 (7):1503-1513. Available from: <https://www. tandfonline.com/doi/full/10.1081/DRT-120005864>. Accessed: Feb. 6, 2007. doi: 10.1081/DRT-120005864.

SHARAF-ELDEN, YI., et al (1980). A model for ear corn drying. Transactions of the ASAE. 23(5). Pp:1261-1265. Available from: <https://elibrary.asabe.org/abstract.asp?aid=3 $4757 \& \mathrm{t}=1 \&$ redir $=$ aid $=34757 \&$ confalias $=\&$ redir $=[$ volume $=23$ \&issue $=5 \& \operatorname{conf}=$ t\&orgconf $=\mathrm{t} 1980] \&$ redirType $=$ toc_journals . asp\&redirType $=$ toc journals.asp $>$. Accessed: Feb. 8, 2007. doi: $10.13031 / 2013.347 \overrightarrow{57}$

SOYSAL, Y., (2005). Mathematical modeling and evaluation of microwave drying kinetics of mint (Mentha spicata L.). Journal of Applied Sciences. 5(7) pp:1266-1274. Available from: <https://

Ciência Rural, v.49, n.7, 2019. 
scialert.net/abstract/?doi=jas.2005.1266.1274>. Accessed: Feb. 8, 2007. doi: $10.3923 /$ jas.2005.1266.1274.

STILING, J., et al (2012). Performance evaluation of an enhanced fruit solar dryer using concentrating panels. Energy for sustainable development. 16. 224-230. Available from: <https://www. sciencedirect.com/science/article/pii/S097308261200004X>. Accessed: Mar. 31, 2012. doi: 10.1016/j.esd.2012.01.002.

TIWARI A. (2016). A Review on Solar Drying of Agricultural Produce. J Food Process Technol. Volume:7 Issue: 9. Available from: $\quad<$ https://www.omicsonline.org/open-access/a-review-onsolar-drying-of-agricultural-produce-2157-7110-1000623.pdf $>$. Accessed: Sep. 21, 2016. doi: 10.4172/2157-7110.1000623.

TOĞRUL, I.T., and PEHLIVAN, D., (2002). Mathematical modeling of solar drying of apricots in thin layers. J. of Food
Engineering. 55 pp:209-216. Available from: <https://www. sciencedirect.com/science/article/pii/S0260877402000651>. Accessed: Dec. 12, 2002. doi: 10.1016/S0260-8774(02)00065-1.

VERMA, L.R., et al (1985). Effects of drying air parameters on rice drying models. Transactions of the ASAE. 28. 296301. Available from: <https://elibrary.asabe.org/abstract. asp aid $=32245 \& \mathrm{t}=2 \&$ redir $=$ aid $-32245 \&$ confalias $=t 1 \&$ redir $=$ [volume $=28 \&$ issue $=1 \& \operatorname{conf}=\mathrm{t} \&$ org conf $=\mathrm{t} 1985$ ] $\&$ redirType $=\mathrm{t}$ oc_journals.asp\&redirType $=$ toc_jounals.asp $>$. Accessed: Dec. 15, 2002. doi: $10.13031 / 2013.3224 \overrightarrow{5}$.

YALDIZ, O., et al (2001). Mathematical modelling of thin layer solar drying of Sultana grapes. Energy. 2001; 26. 457-465. Available from: <https://www.sciencedirect.com/science/article/ pii/S0360544201000184>. Accessed: May, 21, 2001. doi: 10.1016/ S0360-5442(01)00018-4. 